\title{
Teaching Fractions in the Primary Education: A Cross-Sectional Study with Brazilian Polyvalents Teachers
}

\author{
Carlos Mometti \\ School of Education, University of São Paulo, São Paulo, Brazil \\ Email: carlosmometti@usp.br
}

How to cite this paper: Mometti, C. (2021). Teaching Fractions in the Primary Education: A Cross-Sectional Study with Brazilian Polyvalents Teachers. Creative Education, 12, 2752-2764. https://doi.org/10.4236/ce.2021.1211203

Received: October 29, 2021

Accepted: November 27, 2021

Published: November 30, 2021

Copyright $\odot 2021$ by author(s) and Scientific Research Publishing Inc. This work is licensed under the Creative Commons Attribution International License (CC BY 4.0).

http://creativecommons.org/licenses/by/4.0/

Open Access

\begin{abstract}
Math Education in Brazil has undergone important changes in the last two decades. Among these, we can highlight those that refer to methods and ways of developing the pedagogical work of Mathematics with children aged 6 to 9 years. Until the end of the 20th century, Brazilian Mathematics Education was directed towards a more technicist teaching, focusing on the development of operational contents and without much meaning for students. With some political changes and the growing need for internal investments, Brazil starts to operate within the international standards established by the World Bank and International Monetary Fund, which establish as a priority for the granting of loans, the increase of educational levels, and the eradication of illiteracy. In view of this scenario, and allied to the evolution of curricular discussions, Brazilian basic education, mainly in the primary (6 to 10 years), started to incorporate more and important elements related to the teaching methodologies of Mathematics in its discussions, which knowledge teacher occupies the central point. In this sense, the present paper seeks to understand how polyvalent teachers, pedagogues who work in the teaching of Mathematics in the early years, teach the content of fractions and what the essential aspects regarding the methods chosen for this purpose are. Therefore, the research information sources were obtained in a continuing education course with teachers working in public education systems. Such sources were characterized by records of responses to a problem-situation. Data were obtained from the ipsis litteris transcription of these responses, followed by the Content Analysis (CA), assuming the registration units as the initial parameter. As a result, the research evidenced three categories in which the contents discussed by the professors are classified: technicist, undifferentiated method and non-technicist. In addition, the study evidenced the difficulties of teachers in the focus group in differentiating methods from concepts, thus assum-
\end{abstract}


ing different meanings for the fractions.

\section{Keywords}

Cross-Sectional Study, Content Analysis (CA), Primary Education, Fractions

\section{Introduction}

According to Fiorentini (2009) the ways in which Mathematics was conceived in Brazil, especially in the last decade of the $20^{\text {th }}$ century, were characterized by the remnants of the constructivist movement. In this way, issues such as method and ways of teaching, often interpreted in the literature under the relativized mode of pedagogical practice, are set aside in favor of a purely subjectivist interpretation perspective, that is, that practice is built in practice and the context is what regulates the pedagogical modus operandi.

Furthermore, studying pedagogical practice is necessary, since we understand it as a set of techniques and procedures used by the teacher intentionally and with the purpose of achieving a pedagogical learning objective (Franco, 2015; Mometti, 2021b). About this conception, we emphasize the importance of the term "intention".

Therefore, every teacher, regardless of the level, must employ an intention in their teaching process. If we want our students to learn specific content we must in an organized and systematic way have intentionality. Added to this, we have the issue of praxis as a substantial element in this intentional process, as Vázquez (1977) helps us. In this way, we consider praxis as the set of actions, understood here in the sense of action and modification of context and reality, that the teacher develops for a period of time. Therefore, intentionality mobilizes praxis, which in turn builds a temporality and thus defines pedagogical historicity.

It is precisely in this historicity that the field of studies of the pedagogical practice field because if we consider the theoretical contributions brought by Tardif (2002) on teaching knowledge and its performance in pedagogical work, we will find the element "experiential knowledge" as one of the categories. This means that, for this author, the teacher incorporates, to a large extent, the knowledge necessary for the development of his work based on what he learns as a student and what he conceives as an element of success throughout his teaching history.

In this regard, we have shown in another study that knowledge incorporated through experience, as highlighted by Tardif (2002), contributes to the development of forms of awareness that significantly influence classroom practice and teacher performance (Giddens, 2013; Mometti, 2021a).

Moreover, in the last two decades, Math Education has presented countless discussions that have contributed to teacher practice. Among these, we highlight the curricular aspects of the formation of those who teach Mathematics, the me- 
thodologies for their teaching and new theoretical contributions that currently support the development of new research. Thus, it is necessary to investigate not only the pedagogical practices of teachers who work in the Primary Education (6 - 10 years), called polyvalent but also the modus operandi of how such practices can be thought of from experience combined with theory, the result of research.

In this sense, this article aims to present a cross-sectional study developed with Brazilian polyvalents teachers from the Primary Education (6 - 10 years), about the methodological choices for teaching fractions. For that, we used the analysis of methodological proposals prepared by an amount of 15 polyvalent teachers in a continuing education course developed at the second semester of the year 2020 .

Thus, we initially present a theoretical framework about the teaching of fractions, followed by the chosen methodological design and the presentation of results. In a second moment, we discuss their interpretation. Finally, we hope that this work can contribute to advancing the discussion of the methodological approaches used in teaching fractions in the Primary Education (6 - 10 years), as well as for Math Education as an area of knowledge.

\section{Theoretical Frame}

\subsection{About the Fractions}

The teaching of fractions has been studied by researchers in the field of Math Education for some decades. Its importance lies in the fact that this is one of the most relevant contents for the understanding of other areas of Mathematics itself, as well as other areas of knowledge.

Thus, assuming the content of fractions as the object of study of the present research, we can highlight three essential characteristics: 1) construction of the meaning of fractions by those who teach them, 2) meaning of fractions by those who learn them and 3) methods and techniques used to teach them. The first and third refer, basically, to the range of studies carried out on teaching, that is, they assume the teacher who teaches mathematics as a privileged subject of research. The second, in turn, deals with learning, highlighting the student as the subject of the study.

However, it is worth noting that any research of an educational nature must, essentially, consider the teaching and learning process, focusing on the object of interest privileged by the initial objectives (Esteban, 2010; Weller \& Pfaff, 2013). The work in question falls under the third point mentioned above and, therefore, assumes as research subjects the teachers who teach Mathematics in the Primary Education (6 - 10 years).

Furthermore, when it comes to the construction of the meaning of fractions, both by the teachers who teach them and by the students who learn them, we can find, in the literature, authors such as Campos et al. (2006), Friz et al. (2008), Ubah and Bansilal (2018) and Mocrosky et al. (2019), whose studies point to some specific categories of meanings that appear the most, about fractions. 
Therefore, Campos et al. (2006) highlight the following understandings that can be found for fractions: 1) fraction as a part-whole relationship, 2) fraction as quotient, 3) fraction as a multiplier factor, 4) fraction as a number and 5) fraction as a measure. It is worth noting that this research's understanding of meaning is the same attributed by Abbagnano (2018: p. 1055), who emphasizes that meaning deals with the possibility of a sign referring to its object, highlighting two fundamental aspects: a name and the object itself.

Thus, according to the cited authors, the meaning of fraction given by category (1) refers to a piece of a considered total, that is, to a subset of a given set. This meaning is attributed through problems and exercises that consider, for example, the following: Bia ate a quarter of the chocolate bar. Paint the corresponding amount Bia ate.

Category (2), in turn, refers to the interpretation of fractions as a division operation, that is, when finding the mathematical symbolic representation of the form $4 / 2$, the student understands that it is a division of 4 by the quantity 2 . Such meaning can be found in problems like as: one pizza divided for six people, a few balloons divided for two children, among others. According to Ubah and Bansilal (2018), this meaning is the one that most appears in the most advanced levels of basic education, since it requires the operationalization between two quantities represented mathematically.

Regarding category (3) of the meaning of fractions, we can find it in problems as follows: how much corresponds to $1 / 3$ of a package with 60 bullets? The attribution of meaning in this category, according to Friz et al. (2008), is more present at the High School level of basic education, which would correspond to Brazilian Secondary Education. To compare this assertion, it is emphasized that the interpretation of fractions as a multiplicative factor basically comprises the attribution of two sub-meanings, which are: 1) fraction as quantity and 2) fraction as operation.

Furthermore, such sub-meanings are found in the second level of thought, that of operationalization, since, first, the student assigns meaning and interprets the quantities and/or variables involved in the situation that is required to, later, operationalize with them. In the first, we can highlight the pioneering studies of Duval (2011) about semiotics and its contributions to the teaching of mathematics.

The category (4), on the other hand, concerns the quantities that are not defined within the problem, which cannot yet be characterized as variables. This category of fraction meaning can be found in problems like: what is the value corresponding to $1 / 5$ in decimal number? In addition to this, we can also find its use in the representation of numerical sets, such as rational and irrational ones. Finally, in category (5), according to Campos et al. (2006), the attribution of meaning through existing variables stands out, such as in statistical problems involving the calculation of probabilities.

Thus, by the categories of meanings attributed to the fractions mentioned, it is inferred that such diversity can be a source of confusion in the teaching process. 
So, as one of the hypotheses of this research, the reference to such meanings of fractions, by the teacher, during his methodological choice for teaching, stands out. In other words, we want to say that the failure to understand what meaning is transposed to the student can be evidenced by their methodological choice to work with such content.

\subsection{Brazilian Polyvalents Teachers}

It is known that teachers who develop their study in the first years of elementary school, in Brazil, have a degree in Pedagogy and, therefore, are not specialists in the field of Mathematics. It is worth noting, regarding the mandatory training in Pedagogy for these professionals, that this came with the enactment of Law 9394 of December 20, 1996, also known as the Law of Guidelines and Bases of Education, which provides for the organization of Brazilian education, public education, mandatory basic education, and related measures.

In this way, we understand a multipurpose teacher as a professional in education trained in Pedagogy and who works in the early years of elementary school. The reference through the polyvalent name refers to the fact that this professional acquires multidisciplinary training, without going deeper into any of them, highlighting only the basic and essential aspects for the development of their pedagogical work in the Primary Education.

Studies developed by Gatti and Nunes (2009), Proença (2015), Julio and Silva (2018), Ortega and Santos (2018), Ubah and Bansilal (2018), and Mometti (2020a; 2020b) show us the difficulties, on the part of the polyvalent teachers, about the mathematical content, the main factors contributing to this being: 1) absence or few specific subjects for Mathematics Education, in their curriculum, during initial training, 2) the difficulties in the mathematical content brought of their basic training, 3) the absence of pedagogical methods for specific contents of Mathematics, 4) the "dislike" of Mathematics, as an incorporated cultural element, and 5) the lack of structure, didactic resources and technological devices that assist the pedagogical work. Without a shadow of a doubt, these aspects are just some of the countless others that we believe exist, as aggravating elements of the difficulties faced by polyvalents teachers during the teaching of Mathematics.

In this sense, we are guided by the following factors regarding the training of the polyvalent teacher: a) the importance of offering and investing in continuing education courses, to fill and, at the same time, update certain methodological gaps and b) promote space and place to talk for teachers to exchange their experiences and learn from cultural elements experienced in other spaces and cultures.

As the last theoretical contribution that guides us in this research, we highlight the socio-cultural aspects brought by Giddens (2013) and Sewell Jr. (2005). Such contributions refer to the characterization of the teacher's pedagogical work as an action carried out within a substructure called the classroom. Therefore, this action is defined as an agency of the teacher (an individual who con- 
stitutes the social group) and substructure as a set of medium-scale schemes and resources (human and non-human) inserted in a larger structure, characterized, in this case, by the network of education to which it belongs. This perspective is brought from the social structuralism developed by Giddens (2013), with socio-historical theoretical support from Sewell Jr. (2005). Regarding the action of the individual, in our case the multipurpose teacher who teaches mathematics, this can be understood as the schemes from which he develops his work.

\section{Methodological Design}

This work is characterized by a cross-sectional study, as it is in a specific period and with a universe of specific individuals. Thus, our universe comprised 15 polyvalent teachers from the first years of elementary school, working in municipal public schools in four cities in the State of São Paulo and one city in the State of Espírito Santo, Brazil.

We assumed as the context of the research a continuing education course promoted during the second half of 2020, in the remote mode, for 150 teachers from public schools. However, the course was distributed in kindergarten (2 - 5 years) and Primary Education modalities. For this research, we focus on the Primary Education (6 - 10 years).

Furthermore, it should be noted that this course is an integral activity in the schedule of a broad research project entitled Math Education in the Primary Education: Methodological Aspects of Teaching, developed at the University of São Paulo, São Paulo, Brazil. This project comprises an in-depth study of the teaching methodologies of Mathematics in the primary education focusing, essentially, on the training of teachers who teach Mathematics.

As sources of information for this study, we used one of the activities sent by the Virtual Learning Environment (VLE), by a sample of 15 polyvalent teachers participating in the continuing education course. This activity consisted of the elaboration of a proposal to solve a problem, faced by a hypothetical teacher, about the teaching of fractions. All activities were sent via electronic form, which was transcribed ipsis litteris, thus constituting our body of data for analysis.

The second source of information used consisted of observations recorded in the researcher's diary, which were collated during the analysis to assist in the interpretation of the results obtained. In addition, the audiovisual recording of the synchronous remote class, developed on the theme of fractions, with the multipurpose teachers, is also characterized in this work as a source of information. It should be noted that both the recording and the other data obtained to comply with the provisions of Brazilian resolutions No. 466 of December 12, 2012, and No. 510 of April 7, 2016 (Resolução n 510/2016 de 7 de abril do Ministério da Saúde/Conselho Nacional de Saúde, 2016; Resolução nº 466/2012 de 12 de dezembro do Ministério da Saúde/Conselho Nacional de Saúde, 2012) regarding the performance of scientific research with human beings.

Regarding the method of analyzing data transformed from information 
sources, we used the content analysis proposed by Bardin (1977). Such a method consists in the interpretation of the explicit content by the enunciator of a given speech, through the elaboration of representative categories that describe what was thought. Thus, the discourse used is of the written type and the registration units used are documentary, that is, we use the data obtained through the ipsis litteris transcription of the responses sent to the formulated problem-situation, on the methodology of teaching fractions.

The categories obtained a posteriori, that is, resulting from the analysis process of the registration units, were confronted with the provisions of the theoretical contributions on which we base ourselves, thus obtaining the interpretation of what polyvalent teachers understand by methodology, as far as it is concerned respect to teaching fractions.

\section{Results and Discussion}

As highlighted, this work aims to present a cross-sectional study developed with multipurpose teachers from the early years, about the methodological choices for teaching fractions. Initially, we obtained data from the ipsis litteris transcripts of fifteen responses sent to an activity in the VLE, which was a problem-situation with a hypothetical teacher named Clarissa.

Thus, the teachers participating in the course, in this case, our sample of fifteen teachers, should answer the following question: Clarissa is a $4^{\text {th }}$-grade teacher at a municipal school. During her bimonthly planning, she noticed that one of the curriculum components that should be worked on was fractions. In addition, she verified that such a component should return in the successive two months. Given this situation, how could Clarissa "work" this content in the $4^{\text {th }}$ year?

With the data obtained from the answers to the previous situation, experienced by teacher Clarissa, the first movement of formation of registration units for an initial categorization was started, according to Bardin (1977). The categories arising from this first process, in this work named by initial categories, were obtained considering the following criteria: 1) principle of mutual exclusion, 2) principle of intracategory homogeneity, 3) relevance to the objective of the study, 4) relevance to the content spoken by the speaker, and 5) objectivity. Such categories are represented in the first column of Table 1.

In a second moment, from the crossing with the information described in the researcher's diary, the categories that contained some degree of comparability were regrouped. Such categories, in this study, are classified as intermediate level and are represented in the second column of Table 1.

After obtaining the intermediate categories, in a movement to resume the analyzed data, comparing them with the audiovisual recording and, also, the observations recorded in the researcher diary, three categories were obtained that translate the set of contents, about the methodology, cited by the fifteen teachers in the documented speech. Such categories, in this study, are named by representative categories and are in the third column of Table 1. 
Table 1. Primary, intermediate, and representative categorization of the analyzed data. Font: elaborated by the author.

\section{Primary categories Intermediate category}

1. Sequence methodology

2. Recognition precedes method choice

3. Sequence of knowledge

4. Method as a sequence of steps

5. Methodology through problem situations

6. Troubleshooting

7. List of exercises

Operationalization of the fraction concept

8. Practical activity

9. Previous knowledge as a determining factor of the method

10. Intervention and continuous mediation

11. Student behavior

12. Content exposure

13. Pedagogical concept

14. Methodology with concrete materials

15. Everyday materials

Didactic resource understood as a method

16. Understanding the concept of fraction

17. Understanding through concept registration

18. Fraction meaning rational number

19. Fraction with measurement meaning

20. Fraction with meaning of quotient

21. Play as a method

22. Everyday situations

Non-technical aspect Non-technicist
Pedagogical

bureaucracy
Representative

category

\section{Sequential procedures}

\section{Understanding the}

Undifferentiated method as the concept method

to be taught

23. Method as storytelling

The three representative categories can be seen in Table 1: technicist, undifferentiated method, and non-technicist. The first refers to the set of contents that brings the teaching methodologies of fractions in the form of technical contents, such as the use of didactic sequences, mathematical operations involving fractions, the operationalization of the concept involved through problems, and the bureaucratization of the teaching process.

In a way, this category does not translate into a novelty, regarding the teaching of Mathematics since its focus is often directed to an operational transfer of content. Methodologies for teaching Mathematics, such as Problem Solving, Mathematical Modeling, Teaching by History of Mathematics, among others, were not mentioned in the speeches. 
Another important element, which adds to the analysis in question, deals with the education of the fifteen teachers that make up our sample. All work in three municipal education networks in the State of São Paulo and underwent initial training through the distance modality. In this focus group, there was no teacher belonging to the cities of the State of Espírito Santo. In addition, all of them already had experience in working with children and, upon completing a Pedagogy course, they took on public positions to act as polyvalent teachers.

During the discussion on the teaching of fractions, in audiovisual recording, we found that a teacher who makes up our focus group pointed out that in the curriculum of the higher education institution in which she graduated there was only one subject focused on Math Education, whose menu included only didactic and little conceptual aspects, specific to Mathematics.

The second category gives us an important point to investigate in the research project: the non-differentiation, on the part of the polyvalent teacher, of the teaching method. By this, we mean that the contents categorized at this level direct the teacher's speech towards a non-identification of what is a method and what is a concept, that is, the teacher was not able to differentiate method from the concept. Thus, we were left with the following question: what are the influences that contribute to this non-differentiation of the method, on the part of the polyvalent teacher? The data analyzed by this research were not enough to answer the previous question, a fact that led us to expand our research schedule, inserting other aspects to be investigated.

Finally, the third category deals with a methodological form mentioned by a few teachers, exactly three, who suggested teaching the content of fractions through playfulness, storytelling, and everyday situations. On the aspect of playfulness, it was not specified in the content whether it would be through games, entertainment activities, or with the aid of toys. Regarding everyday situations, the speech brought as an example the use of school lunches and fruit cutting. Table 2 highlights the relationships between two levels of categorization, which were obtained through content analysis of the fifteen responses sent, about the problem situation involving teacher Clarissa.

We can see that the failure to detail the methodologies that would be used in Clarissa's situation materializes a situation that, possibly and hypothetically, would not only be that of the studied teachers: the non-recognition of the method as an essential stage of student learning. This does not mean, in a way, that the teacher does not have the technique, but that he does not reflect on it from a methodological point of view. Clearly, the knowledge obtained through experience is more representative for this group of teachers than we assume as a focus group.

\section{Conclusion}

The present work sought to present a cross-sectional study developed with a group of fifteen multipurpose teachers from the early years, about the methodological 
Table 2. Relation between intermediate and representative categories. Font: elaborated by the author.

\begin{tabular}{|c|c|c|}
\hline Intermediate category & Principal content & $\begin{array}{l}\text { Representative } \\
\text { category }\end{array}$ \\
\hline Sequential procedures & $\begin{array}{l}\text { Shows the method as a succession of } \\
\text { procedures applied to achieve the } \\
\text { expected objective of the class }\end{array}$ & \\
\hline $\begin{array}{l}\text { Operationalization of the } \\
\text { fraction concept }\end{array}$ & $\begin{array}{l}\text { Highlights the mathematical operations } \\
\text { using the fraction as a technical method } \\
\text { for the development of the process }\end{array}$ & Technicist \\
\hline Pedagogical bureaucracy & $\begin{array}{l}\text { Highlights the pedagogical steps } \\
\text { necessary for the development of the } \\
\text { process }\end{array}$ & \\
\hline $\begin{array}{l}\text { Didactic resource } \\
\text { understood as a method }\end{array}$ & $\begin{array}{l}\text { Highlights the non-differentiation, on the } \\
\text { part of the teacher, of what is a method } \\
\text { and what is a didactic resource for the } \\
\text { teaching of the concept }\end{array}$ & $\begin{array}{l}\text { Undifferentiated } \\
\text { method }\end{array}$ \\
\hline $\begin{array}{l}\text { Understanding the method } \\
\text { as the concept to be taught }\end{array}$ & $\begin{array}{l}\text { Highlights the non-differentiability, on } \\
\text { the part of the teacher, of what is a } \\
\text { method and what is a concept }\end{array}$ & \\
\hline Non-technical aspect & $\begin{array}{l}\text { Highlights games and playfulness as a } \\
\text { teaching method }\end{array}$ & Non-technicist \\
\hline
\end{tabular}

choices for teaching fractions. Thus, we were able to evidence, through the content analysis proposed by Bardin (1977), three representative categorizations of discursive contents by the group of analyzed teachers. These categories were: technicist, non-differentiation of the method and non-technicist.

Regarding the first category, we could see that the teachers analyzed in the study developed a vision focused on the execution of patterns and limited to a set of operationalizations, as shown in Table 2. The second category, in turn, showed us in this same group of teachers analyzed that there is no specific understanding of what teaching method is, in this research interpreted as a technique, a procedure according to Franco (2015) and Mometti (2021b), of the purely conceptual content. This means that when teaching the content of fractions, the analyzed teachers treat it as something that must be learned based on the assumption that it is knowledge "absorbed by the student", which does not require specific teaching technique and/or movement depending on the group of children who are working. This gives us a very trivial consideration of contemporary education about the teacher's role in teaching and its importance as an agent that modifies the pedagogical space, so well discussed by Meirieu (2002). Furthermore, working with fractions, or any other content in Mathematics, requires intentionality as highlighted by Franco (2015), so one must be concerned with the set of procedures necessary for a given pedagogical objective to be achieved. 
Finally, regarding the third and last category found by this study, we highlight the teachers who do not bring to light their pedagogical practice analyzed for this case an evident concern with the procedures used to teach a mathematical content, which does not mean that they are not concerned with teaching him. This reflects the constructivist pedagogical approach still very present in Brazil

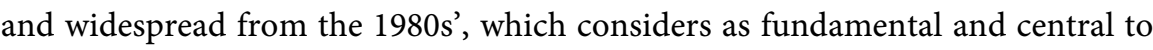
the student's learning process, in general, its time, its historicity, and its participation in the then "construction of knowledge", as highlighted by Mortatti (2014) contextualizing with literacy for Brazilian children, as well as Krasilchik (1987) dealing with Science Education.

Thus, in a second moment, the categories mentioned gave us the understanding that the methodological choices for teaching fractions from the problem situation of teacher Clarissa were of a technical, conceptual, and technical nature, and totally non-technical. This means diversity in terms of teachers' understanding of how to teach certain contents, as well as the problem of not differentiating method from content, as interpreted previously. This fact raised a research question that was incorporated into our studies, which is: how does the teacher of the early years differentiate between method and concept in relation to Mathematics? This question will be part of a later stage to be developed in our studies on the methodology of teaching Mathematics in primary education.

In a third moment, we could perceive and understand that the debate about what would be the best method to teach Mathematics to children aged 6 to 10 still occupies a prominent point among the surveyed teachers. In this sense, it is noteworthy that, in the initial training of the studied polyvalent teachers, the treatment is given to teaching methodologies generally places them associated with the pedagogical-bureaucratic, that is, they were centered on the teacher and on his behavior when in his classroom. But when it comes to teaching, we also have the content needed for student learning.

Thus, it is still necessary and urgent to understand what the multipurpose teacher understands about teaching methodology and what are their conceptions about this process, so that, later, we can think about specific courses that bring good results to their pedagogical work. Such continuing education courses are essential for the teacher's own development, since, as pointed out by Gatti and Nunes (2009), there are few teachers' education courses in Brazil that present a significant number of disciplines that properly develop the necessary bases for good teaching performance.

Finally, we hope that this research will bring contributions to the area of teacher education who teach mathematics as well as to the teachers participating in the research, who are still in contact with the project's research team for collaboration and exchange of experiences.

\section{Acknowledgements}

We are grateful for the support given by the Coordination for the Improvement 
of Higher Education (CAPES), of the Ministry of Education of Brazil, through the granting of research resources given by project number 88882.378062/2019-01.

\section{Conflicts of Interest}

The author declares no conflicts of interest regarding the publication of this paper.

\section{References}

Abbagnano, N. (2018). Dicionário de Filosofia. Tradução de Ivone Castilho Benedetti. Editora Martins Fontes.

Bardin, L. (1977). Análise de Conteúdo. Edições 70.

Campos, T. M. M., Magina, S. E., \& Nunes, T. (2006). O Professor polivalente e a fração: Conceitos e estratégias de ensino. Revista Educação Matemática e Pesquisa, 1, 125-136.

Duval, R. (2011). Ver e ensinar a matemática de outra forma (1st ed.). Proem.

Esteban, M. P. S. (2010). Pesquisa Qualitativa em Educação: Fundamentos e Tradições. Tradução Miguel Cabrera. Amgh.

Fiorentini, D. (2009). Alguns modos de ver e conceber o ensino da matemática no Brasil. Zetetike, 3, 1-37.

Franco, M. A. S. (2015). Práticas pedagógicas de ensinar-aprender: Por entre resistências e resignações. Educação e Pesquisa, 41, 601-614. https://doi.org/10.1590/S1517-9702201507140384

Friz, M. C., Sanhueza, S. H., Sánchez, A. B., Mellado, M. B., \& Manzi, E. F. (2008). Propuestas Didácticas para el desarrollo de competencias Matemáticas en Fracciones. Horizontes Educacionales, 2, 87-98.

Gatti, B., \& Nunes, M. M. R. (2009). Formação De Professores Para O Ensino Fundamental: Estudo De Currículos Das Licenciaturas Em Pedagogia. Fundação Carlos Chagas-Pesquisas Educacionais.

Giddens, A. (2013). A Constituição da Sociedade. Tradução de Alvaro Cabral. Martins Fontes.

Julio, R., \& Silva, G. H. G. S. (2018). Compreendendo a formação matemática de futuros pedagogos por meio de narrativas. Bolema, 32, 1012-1029.

https://doi.org/10.1590/1980-4415v32n62a13

Krasilchik, M. (1987). O professor e o currículo das ciências. EPU/Edusp.

Meirieu, P. (2002). A pedagogia entre o dizer e o fazer: A coragem de começar. Artmed.

Mocrosky, L. F., Orlovski, N., Tychanowicz, S. D., Andrade, S. P., \& Panossian, M. L. (2019). Frações na formação continuada de professoras dos anos iniciais: Fragmentos de uma complexidade. Bolema, 33, 1444-1463. https://doi.org/10.1590/1980-4415v33n65a22

Mometti, C. (2020a). Experiência de Formação Continuada para Polivalentes: O Sistema de Numeração Decimal na Prática Pedagógica. Anais do XIV Encontro Paulista de Educação Matemática.

https://drive.google.com/file/d/1EeTFJIySPBODpZoYDH1pOC07iyYuGu9X/view

Mometti, C. (2020b). A Escola Digital: Repensando a Prática Pedagógica na Educação Matemática. Anais do VIII Encontro Brasiliense de Educação Matemática, Sociedade Brasileira de Educação Matemática. https://www.even3.com.br/anais/viiiebrem/

Mometti, C. (2021a). As consciências sociológicas de professores polivalentes na Edu- 
cação Matemática. ReDiPE: Revista Diálogos e Perspectivas em Educação, 3, 148-264. https://periodicos.unifesspa.edu.br/index.php/ReDiPE/article/view/1564

Mometti, C. (2021b). O saber necessário à prática docente na humanidade digital. Revista De Educação Matemática, 18, e021010. https://doi.org/10.37001/remat25269062v17id482

Mortatti, R. L. (2014). Produção acadêmica brasileira sobre alfabetização: Avaliação da qualidade e impacto cientíico e social. In: Alfabetização e seus sentidos: o que sabemos, fazemos e queremos? Maria do Rosário Longo Mortatti, Isabel Cristina Alves da Silva Frade (org.). Oficina Universitária.

Ortega, E. M. V., \& Santos, V. M. (2018). A Relação Dos Alunos Do Curso De Pedagogia Com O Conhecimento Matemático E Seu Ensino: Um Estudo Longitudinal. Revista Holos, 2, 207-224. http://www2.ifrn.edu.br/ojs/index.php/holos/issue/view/140

Proença, M. C. (2015). O Ensino De Frações Via Resolução De Problemas Na Formação De Futuras Professoras De Pedagogia. Bolema, 29, 729-755. https://doi.org/10.1590/1980-4415v29n52a15

Resolução $\mathrm{n}^{\circ}$ 466, de 12 de Dezembro do Ministério da Saúde/Conselho Nacional de Saúde (2012). Diário Oficial da União.

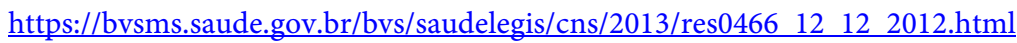

Resolução ${ }^{\circ}$ 510, de 7 de Abril do Ministério da Saúde/Conselho Nacional de Saúde (2016). Diário Oficial da União. edição 8, seção I, 44.

https://bvsms.saude.gov.br/bvs/saudelegis/cns/2016/res0510 0704 2016.html

Sewell, W. H. (2005). Logics of History: Social Theory and Social Transformation. Chicago University Press. https://doi.org/10.7208/chicago/9780226749198.001.0001

Tardif, M. (2002). Saberes docentes e formação profissional. Editora Vozes.

Ubah, I. J. A., \& Bansilal, S. (2018). Pre-Service Primary Mathematics Teachers' Understanding of Fractions: An Action-Process-Object-Schema Perspective. South African Journal of Childhood Education, 8, A539.

Vázquez, A. S. (1977). Filosofía da praxis (2nd ed.). Paz e Terra.

Weller, W., \& Pfaff, N. (2013). Metodologias Da Pesquisa Qualitativa Em Educação: Teoria E Prática (3rd ed.). Editora Vozes. 